\title{
Differential Diagnosis of Anemia in Patients with Rheumatoid Arthritis
}

\author{
Mykola VATUTIN, Ganna SMYRNOVA, Anna SHEVELYOK, Olga KASHANSKA, \\ Olena SKLYANNA, Olena KETING
}

Department of Internal Medicine, Maxim Gorky National Medical University, Donetsk, Ukraine

\begin{abstract}
Objectives: This study aims to identify laboratory markers which can be used to distinguish between the different types of anemia in patients with rheumatoid arthritis (RA).

Patients and methods: Ninety patients who met the American College of Rheumatology (ACR) criteria for RA and the World Health Organization (WHO) criteria for anemia were included in this study. We evaluated the hematocrit, color index, serum iron, ferritin, transferrin, and erythropoietin (EPO) levels along with the total iron binding capacity (TIBC) and mean erythrocyte volumes. Iron deficiency anemia (IDA) was defined as serum ferritin levels of $<15 \mathrm{ng} / \mathrm{ml}$ ) together with low serum iron levels (IDA group) while anemia of chronic disease (ACD) was defined as having serum ferritin levels of $>15 \mathrm{ng} / \mathrm{ml}$ and normal serum iron levels (ACD group). Those with low serum iron and low/normal ferritin levels were included in the COMBI group, a combination of IDA and ACD (COMBI group).

Results: The serum ferritin concentration was significantly increased and the serum transferrin level was significantly decreased in the IDA group compared with the ACD and COMBI groups. We also observed elevated EPO concentrations in all of the subgroups, but we found relative $E P O$ deficiency only in the $A C D$ and $C O M B I$ groups.

Conclusion: Our findings suggest that the characte-ristics of COMBI anemia encompass the qualities of both ACD and IDA, particularly the latter. A differential diagnosis of anemia in patients with RA should be based on determining the serum iron and ferritin levels as well as the presence of relative EPO deficiency.

Keywords: Anemia; erythropoietin; ferritin; rheumatoid arthritis; total iron binding capacity; transferring.
\end{abstract}

Rheumatoid arthritis (RA) is characterized by hyperplasia of the synoviocytes, especially the synovial fibroblasts, which results in bone and joint destruction. ${ }^{1}$ Recent studies have revealed that cytokines and other mediators of inflammation in the development of RA play a key role in the articular syndrome as well as a whole range of systemic manifestations of the disease. ${ }^{2}$ In particular, anemic syndrome is a very common manifestation of rheumatoid inflammation. According to literature study by Bloxham et al., ${ }^{3}$ anemia develops in $30-70 \%$ of patients with RA. Different types of anemia, including iron deficiency anemia (IDA), anemia of chronic disease (ACD), the combination of IDA and ACD (COMBI) anemia, megaloblastic anemia, and hemolytic anemia, have been seen in patients with RA. Some causes of this blood disorder include changes in iron metabolism due to lesions of the mucous membrane in the gastrointestinal tract resulting from the use of steroids or methotrexate, a shortening of the life of red blood cells (RBCs), and the inadequate production of RBCs by the bone marrow. ${ }^{4}$ Acknowledging the characteristics

Received: March 24, 2013 Accepted: September 16, 2013

Correspondence: Ganna Smyrnova, M.D. Department of Internal Medicine, Maxim Gorky National Medical University, No: 1, 83003, Donetsk, Ukraine.

Tel: +380509159666 e-mail: a.smyrnova@mail.ru

(02014 Turkish League Against Rheumatism. All rights reserved. 
of the different types of anemia is vital since the beneficial effect of iron supplementation seen in IDA and COMBI anemia could be harmful in patients with $A C D$, whereas iron supplementation without EPO administration might be insufficient in those with COMBI anemia because the added iron in ACD patients is free to nourish bacteria and cancer cells. The pathogenesis of COMBI anemia includes not only iron deficiency but EPO insufficiency.

Therefore, the purpose of our study was to determine the laboratory markers that can be used to distinguish between the different types of anemia in patients with RA.

\section{PATIENTS AND METHODS}

The investigated population consisted of 90 anemic patients who were at least 18 years old who fulfilled the American College of Rheumatology (ACR) criteria for RA and were willing to participate in the study. In addition, they also met the World Health Organization (WHO) criteria for anemia which uses a hemoglobin $(\mathrm{Hb})$ threshold of $<120 \mathrm{~g} / 1$ for women and $<130 \mathrm{~g} / 1$ for men. ${ }^{5}$ The patients were assigned to one of three groups on the basis of their iron status and clinical data. The first group was composed of 32 female patients (mean age 46.3 years) who fulfilled the criteria of iron deficiency (serum ferritin levels $<15 \mathrm{ng} / \mathrm{ml}$ and low iron levels), and these were classified as having IDA. ${ }^{6}$ The second group was made up of 29 anemic female patients (mean age 45.8 years) with serum ferritin levels $>15 \mathrm{ng} / \mathrm{ml}$ and normal serum iron levels, and these were categorized as having ACD. The third group was composed of 29 anemic patients (10 females and 1 male; mean age 46.2 years) who had low serum iron levels and low/normal ferritin levels, and these made up the COMBI group. Patients with a history of other inflammatory or noninflammatory arthritis, megaloblastic anemia, malignancies, renal disease with severe renal insufficiency, chronic infectious and inflammatory diseases, and other diseases in the stage of decompensation were excluded from the study. The local ethics committee of the National Medical University in Donetsk, Ukraine gave their approval.
Blood samples were collected using the Sarstedt tube system (Sarstedt Inc., Nümbrecht, Germany). The serum was separated by centrifugation at $3300 x g$ for 15 minutes and immediately frozen at $-20{ }^{\circ} \mathrm{C}$ until tested. The blood count was then measured electronically by the ABX Micros ES 60 hemotology analyzer (Horiba ABX SAS, Montpelier, France), and the serum iron and transferrin levels as well as the total and latent iron binding capacities (TIBC and LIBC) were measured using the ferrozine method based on a photometric color test utilizing the Cobas 6000 analyzer (Roche Diagnostics, Basel, Switzerland). The ferritin levels were measured via electrochemiluminescence immunoassay (ECLIA) technology (Roche Diagnostics, Basel, Switzerland), and the EPO levels were measured by an improved Immulite enzymelinked immunosorbent assay (ELISA) system (Siemens AG, Berlin, Germany). The presence of relative EPO deficiency (in relation to the degree of anemia) was analyzed in each patient by calculating the ratio between the observed $(\mathrm{O})$ and predicted $(\mathrm{P})$ logarithm of the baseline serum EPO concentration, ${ }^{7}$ and the following formula was used $\log (\mathrm{EPO})=4.746-(0.093 \times$ packed red cell volume $)$ for patients with a packed red cell volume of $<38 \%$, and $\log (\mathrm{EPO})=1.381-(0.005 \mathrm{x}$ packed red cell volume) for patients with a packed red cell volume of $>38 \%$. An $\mathrm{O} / \mathrm{P}$ ratio value of $<1.0$ indicated an inadequate endogenous EPO concentration with respect to the degree of anemia.

Statistical analyses were performed using the MEDSTAT version 4.0 for Windows software program (The MEDSTAT Group, Inc., Ann Arbor, MI). The Shapiro-Wilk normality test was employed to assess whether or not the data was normally distributed, and descriptive data was presented as mean \pm standard deviation (SD) because the data was distributed normally. Univariate analysis of variance (ANOVA) and Scheffe's test was conducted for subgroup comparisons, and we performed a Bonferroni correction on the critical alpha value. The Bonferroni differences were considered to be statistically significant at $\mathrm{p}<\mathrm{p} 0 / \mathrm{n}[\mathrm{p} 0=$ the initially specified level of statistical significance $(p=0.05)$ and $n=$ the number of subgroup comparisons], and the new critical value was $0.05 / 3=0.0166$. We then compared the $p$ value resulting from the $\mathrm{T}$-test with this Bonferroni corrected alpha level (0.0166). 


\begin{tabular}{|c|c|c|c|c|}
\hline Laboratory test & $\begin{array}{l}\text { ANOVA } \\
p \text { values }\end{array}$ & $\begin{array}{c}\text { Differences between } \\
\text { the IDA and ACD } \\
\text { groups } \\
\text { ( } p \text { with Bonferroni } \\
\text { correction) }\end{array}$ & $\begin{array}{l}\text { Differences between } \\
\text { the ACD and COMBI } \\
\text { groups } \\
\text { ( } p \text { with Bonferroni } \\
\text { correction) }\end{array}$ & $\begin{array}{c}\text { Differences between } \\
\text { the IDA and COMBI } \\
\text { groups } \\
\text { ( } p \text { with Bonferroni } \\
\text { correction) }\end{array}$ \\
\hline Hemoglobin $(\mathrm{g} / \mathrm{l})$ & $<0.001$ & 0.013 & $<0.003$ & $<0.003$ \\
\hline Color index & $<0.001$ & $<0.003$ & $<0.003$ & $<0.003$ \\
\hline Mean erythrocyte volume $\left(\mathrm{mcm}^{3}\right)$ & $<0.001$ & $<0.003$ & $<0.003$ & $<0.003$ \\
\hline Total iron binding capacity $(\mathrm{mmol} / \mathrm{l})$ & $<0.001$ & $<0.003$ & 0.013 & 0.02 \\
\hline Serum ferritin $(\mathrm{ng} / \mathrm{ml})$ & $<0.001$ & $<0.003$ & $<0.003$ & $<0.003$ \\
\hline Serum transferrin $(\mathrm{g} / \mathrm{l})$ & $<0.001$ & $<0.003$ & $<0.003$ & 0.013 \\
\hline Serum erythropoietin (mIU/ml) & $<0.001$ & $<0.003$ & 0.013 & $<0.003$ \\
\hline Observed/predicted log(Epo) & $<0.001$ & $<0.003$ & $<0.003$ & $<0.003$ \\
\hline
\end{tabular}

\section{RESULTS}

The $\mathrm{Hb}$ concentration in the COMBI anemia patients $(97.39 \pm 5.03 \mathrm{~g} / \mathrm{l})$ was lower than in the IDA $(100.51 \pm 5.43 \mathrm{~g} / \mathrm{l})$ and ACD groups $(103.47 \pm 5.54 \mathrm{~g} / \mathrm{l})$, whereas the color index level and mean erythrocyte volume were lower in the IDA patients $\left(0.68 \pm 0.06 ; 5.96 \pm 0.24 \mathrm{mcm}^{3}\right)$ than in the ACD $\left(0.92 \pm 0.04 ; 7.73 \pm 0.23 \mathrm{mcm}^{3}\right)$ and COMBI groups $\left(0.72 \pm 0.06 ; 6.38 \pm 0.83 \mathrm{mcm}^{3}\right)$ (Table 1). Additionally, the TIBC in the IDA patients $(79.34 \pm 3.02 \mathrm{mmol} / \mathrm{l})$ showed a propensity toward increased values compared with the ACD group $(52.27 \pm 5.36 \mathrm{mmol} / \mathrm{l})$, but no statistically significant differences were noted between the IDA and COMBI $(67.34 \pm 15.53 \mathrm{mmol} / \mathrm{l})$ patients. Furthermore, the serum ferritin concentration was significantly increased and the serum transferrin level was significantly decreased in the IDA $(10.56 \pm 1.04 \mathrm{ng} / \mathrm{ml} ; 11.34 \pm 5.61 \mathrm{~g} / \mathrm{l})$ group compared with the ACD $(108.41 \pm 14.87 \mathrm{ng} / \mathrm{ml}$; $2.41 \pm 0.27 \mathrm{~g} / \mathrm{l})$ and COMBI $(33.05 \pm 38.54 \mathrm{ng} / \mathrm{ml}$;
$9.49 \pm 5.24 \mathrm{~g} / \mathrm{l})$ groups. We also observed elevated EPO concentrations in all of the subgroups (IDA 135.27 \pm 4.68, ACD 54.43 \pm 11.34 , and COMBI $63.61 \pm 26.18 \mathrm{mIU} / \mathrm{ml}$ ), but we found relative $\mathrm{EPO}$ deficiency only in the ACD and COMBI groups (IDA $1.01 \pm 0.01$; ACD 0.36 \pm 0.04 ; COMBI $0.41 \pm 0.03$ ).

Thus, our results showed that IDA in patients with RA is characterized by $\mathrm{RBC}$ microcytosis and hypochromia, a reduction in serum iron and ferritin levels, and an increase in serum transferrin and erythropoietin concentrations (Table 2). We also determined that patients with ACD present with a normocytic and normochromic blood picture. They also have normal serum iron levels, TIBC, and transferrin concentrations together with normal/elevated ferritin levels, elevated EPO concentrations and relative EPO deficiency. Moreover, those with COMBI anemia present with a normocytic and normochromic (or occasionally microcytic, hypochromic) blood picture, and this type of anemia is characterized by reduced

\begin{tabular}{|c|c|c|c|}
\hline & IDA & ACD & COMBI anemia \\
\hline Mean erythrocyte volume & Reduced & Normal & Reduced to normal \\
\hline Color index & Reduced & Normal & Reduced to normal \\
\hline Serum iron & Reduced & Normal & Reduced \\
\hline Total iron binding capacity & Elevated & Normal & Normal to elevated \\
\hline Serum ferritin & Reduced & Normal to elevated & Reduced to normal \\
\hline Serum transferrin & Elevated & Normal & Normal to elevated \\
\hline Serum erythropoietin & Elevated & Elevated & Elevated \\
\hline Relative erythropoietin deficiency & No & Yes & Yes \\
\hline
\end{tabular}


serum iron levels, reduced/normal serum ferritin levels, elevated/normal TIBC, elevated/normal serum transferrin concentrations and relative EPO deficiency.

Our findings suggest that the signs of ACD and COMBI anemia in patients with RA had a multidirectional nature. Therefore, the differential diagnosis of these types of anemia in patients with RA should be based on additional measurements of relative EPO deficiency.

\section{DISCUSSION}

Our results were correlated with the study by Ogedegbe et al. ${ }^{7}$ in which they discovered that one of the characteristic features of IDA is a demonstration of microcytic hypochromic RBCs in the peripheral smear. In addition, they found that decreased stores of iron may be demonstrated in the bone marrow aspirate.

Anemia of chronic disease is a prevalent, poorly understood condition that presents with a normocytic and normochromic (or occasionally microcytic and hypochromic) blood picture. It tends to be mild and is overshadowed by the basic disease. It does not usually progress in severity, and the reticulocyte count is not elevated in most cases. The IBC in ACD is normal or decreased (in contrast to IDA in which the IBC is elevated), and the serum ferritin levels are increased. Other characteristics that can be seen with ACD include a blunted $\mathrm{EPO}$ response by the RBC precursors, decreased survival of the RBCs, and defective iron absorption. Defective macrophage iron retention may also contribute to this type of anemia by interrupting iron delivery to the erythroid precursor cells. Furthermore, ACD may be precipitated by impaired iron utilization in which the functional iron levels are low, but the tissue iron levels are normal or high. Moreover, ACD is the second most common form of anemia worldwide after IDA. It is also now clear ${ }^{8}$ that inflammatory cytokines released during ACD can alter systemic iron metabolism by inducing the excess synthesis of hepcidin, the iron regulatory hormone. Since hepcidin inhibits iron exportation from cells by blocking ferroportin activity, the root cause of the hypoferremia and iron-restricted erythropoiesis in ACD can be attributed to the excess hepcidin levels.

\section{Conclusion}

The differential diagnosis of anemia in patients with RA should be based on the serum iron and ferritin levels as well as the presence or absence of relative EPO deficiency. We believe that our findings can help definitively diagnose the type of anemia in patients with RA and provide them with the necessary treatment to improve their quality of health quality, thereby decreasing disease activity. However, future research on a larger scale is needed to validate our findings regarding these laboratory markers and evaluate the clinical effectiveness of the use of these markers in the treatment of ICD, $\mathrm{ACD}$ and $\mathrm{COMBI}$ anemia.

\section{Declaration of conflicting interests}

The authors declared no conflicts of interest with respect to the authorship and/or publication of this article.

\section{Funding}

The authors received no financial support for the research and/or authorship of this article.

\section{REFERENCES}

1. Neumann E, Lefèvre S, Zimmermann B, Gay S, MüllerLadner U. Rheumatoid arthritis progression mediated by activated synovial fibroblasts. Trends Mol Med 2010;16:458-68.

2. Choy EH, Panayi GS. Cytokine pathways and joint inflammation in rheumatoid arthritis. $\mathrm{N}$ Engl $\mathrm{J}$ Med 2001;344:907-16.

3. Bloxham E, Vagadia V, Scott K, Francis G, Saravanan $\mathrm{V}$, Heycock C, et al. Anaemia in rheumatoid arthritis: can we afford to ignore it? Postgrad Med J 2011;87:596-600.

4. Kullich W, Niksic F, Burmucic K, Pöllmann G, Klein G. Effects of the chemokine MIP-1alpha on anemia and inflammation in rheumatoid arthritis. Z Rheumatol 2002;61:568-76.

5. Iron deficiency anaemia. Assessment, prevention and control. A guide for programme managers. World Health Organization, Document WHO/NHD/01.3, Geneva; 2001. p. 115.

6. Osterborg A, Boogaerts MA, Cimino R, Essers U, Holowiecki J, Juliusson G, et al. Recombinant human erythropoietin in transfusion-dependent anemic patients with multiple myeloma and non-Hodgkin's lymphoma--a randomized multicenter study. The European Study Group of Erythropoietin (Epoetin Beta) Treatment in Multiple Myeloma and Non-Hodgkin's Lymphoma. Blood 1996;87:2675-82. 
7. Ogedegbe H, Csury L, Simmons B. Anemias: A clinical laboratory perspective. Lab Medicine 2004;35:177-85.

8. Weinstein DA, Roy CN, Fleming MD, Loda MF, Wolfsdorf
JI, Andrews NC. Inappropriate expression of hepcidin is associated with iron refractory anemia: implications for the anemia of chronic disease. Blood 2002;100:3776-81. 